METABOLIC ENERGY REQUIREMENTS FOR SPACE FLIGHT

Helen W. Lane, Ph.D

Biomedical Operations and Research Branch

NASA-Johnson Space Center

Houston, TX 77058

(NASA-IM-107933) METABDLIC ENERGY

N92-28212 REQUIREMENTS FUR SPACE FLIGHT (NASA) 29 P 
Chapter 8. Metabolic Energy Requirements for Space Flight

\section{Tables and Figures}

Table 8.1. Energy Expenditure in Selected Household, Recreational, and Sports Activities Table 8.2. Nutritional Intake of Skylab Crewmembers

Table 8.3. Respiratory Quotient of Skylab Crewmembers

Table 8.4. Thermal Equivalent of Oxygen for Nonprotein Respiratory Quotient

Table 8.5. Body Weight Changes and Nitrogen Balance in Skylab Crewmembers

Table 8.6. Energy Consumed and Utilized on U.S. Space Shuttle Flights

Table 8.7. EVA Metabolic Rates During 1-g Training and During Flight (Apollo 15)

Table 8.8. Glucose and Insulin Response During 7 days of Bed Rest

Table 8.9. The Effect of Space Flight on Stool Production in 9 Skylab Crewmembers

Figure 1. The U.S. Space Shuttle food service system. [NASA photo no. S83-37097]

Figure 2. Astronaut Robert Crippen prepares to eat a meal on STS-1.

[NASA photo S13080267] 
The international space community, including the USSR, Japan, Germany, the European Space Agency, and the United States, is preparing for extended stays in space. Much of the research planned for space will be tended by humans; thus maintaining adequate nutritional status during long stays in space has lately become an issue of much interest. Historically, it appears that minimum nutritional requirements are being met during stays in space $(1,2)$ : Thus far, crewmembers have been able to consume food adequate for maintaining nominal performance in microgravity. The purpose of this review is to explore the physiological data obtained from ground-based and flight research that may enable us to understand the biochemical alterations that affect energy utilization and performance. This review will focus on energy utilization during the Apollo lunar missions, Skylab's extended space lab missions, and Space Shuttle flights. Available data includes those recorded during intra- and extravehicular activities as well as during microgravity simulation (bed rest). Data on metabolism during flight and during bed rest will be discussed, with a follow-up on human gastrointestinal function.

The energy expended by humans during many Earth-based activities (Table 8.1) has been calculated using a variety of methods. Human energy utilization during space flight has been determined indirectly using several methods, including recording food intake (diet history), metabolic balance studies, food disappearance, and respiratory gas production (2-4). The most detailed nutritional studies were performed during the Skylab missions, which included dietary records in combination with metabolic balance studies (3). The energy levels of Skylab menus were determined directly using bomb calorimetry and indirectly by calculating the amounts of carbohydrate, protein, and fat consumed from crewmember records (see Table 8.2). Energy levels of stools were determined directly by bomb calorimetry and these data were used to calculate energy availability. Apparent energy intake was calculated as energy in the diet minus the energy found in the urine and stools. 
The energy level of the food consumed before flight did not differ from that of the food consumed during flight (Table 8.2). Length of flight had no effect on apparent energy availability from foods consumed: At 28 days, mean energy available in $\mathrm{Kcal}( \pm$ S.D.) was 2686 \pm 141 ; at 59 days, $2939 \pm 538$; and at 89 days, $2972 \pm 78$. For comparison, preflight resting energy expenditure (REE) was also calculated for the Skylab crewmembers using the HarrisBenedict equation (5) (Table 8.1). Apparent energy intake was about $1000 \mathrm{Kcal} /$ day greater than the Harris-Benedict measure of REE. $\therefore$

The type of energy consumed before flight, however, differed from in-flight intake: Carbohydrate intake was significantly higher, and fat intake significantly lower, during flight than before flight. In an effort to identify the primary substrate for energy utilization, we calculated nonprotein respiratory quotients (RQ) from existing measurements of resting $\mathrm{VO}_{2}$ and $\mathrm{VCO}_{2}$ levels (J. Leonard, personal communication). These measurements had been taken before, during, and after flight over 5-minute periods while the subjects were at rest, at three levels of exercise and during recovery. Mean RQ values, corrected for urinary nitrogen, are shown in Table 8.3. Interestingly, the mean RQ during flight was higher than preflight or postflight RQ for all measurements except exercise level 1. An increase in RQ has been interpreted as reflecting a shift from fat to carbohydrate as the primary substrate for energy utilization (Table 8.4) (5). Furthermore, an RQ greater than 1.0 implies the occurrence of lipogenesis (5). The increase in carbohydrate intake during flight and the continued loss of lean body mass (6-7), taken together, support the conclusion that the Skylab crewmembers increased their utilization of carbohydrates during flight (8).

Table 8.5 shows changes in body weight during the Skylab missions. Although Leach and colleagues have estimated a fluid loss of approximately $900 \mathrm{~mL}(8-10)$, some evidence exists that weight loss may include loss of fat and lean body mass as well as fluid (10). The small but persistent negative nitrogen balance during Skylab flights (Table 8.5) suggests that the major 
component of the nonfluid weight change may have been loss of lean body mass. The concurrent presence of an RQ greater than 1.0 and a negative nitrogen balance suggests that some lean body mass may have been replaced with fat. The Skylab crewmembers tended to lose more weight during the shorter flights than the longer ones. The original explanation for this effect was that inadequate energy had been provided during the earlier, shorter flights. During the longest Skylab flight (84 days), both available energy from food and the length of in-flight exercise increased; mean body weight loss, in contrast, decreased. Exercise and increased energy supplied in food therefore appear to counter body weight loss. However, the combination of chronic negative nitrogen balance, maintenance of body weight, and RQ greater than 1.0 suggests that space flight may induce or encourage the replacement of lean body mass with fat (10-11). These interactions will become still more important as the duration of space flights lengthens, and crews undertake the physical work involved in extravehicular activities for Space Station Freedom construction.

Because the Skylab crewmembers consumed metabolic diets as part of the mission, some quantification of nutrient intake, output, and energy utilization was possible. The US Space Shuttle program, in contrast, has no requirement for monitoring individual intake, and therefore the few data that are available reflect only patterns of food consumption among the crews. The Space Shuttle food service system (Figure 8.1) was designed to provide a variety of palatable foods of adequate nutritional quality, in forms compact, safe and convenient for use in microgravity (4). Figure 8.2 shows Astronaut Robert Crippen preparing to eat a meal on STS1. Food products include rehydratable foods and beverages, ready-to-eat meals that can be warmed in an on-board convection oven, low-moisture or canned foods, and some fresh foods such as fruit. All foods are packaged in individual portions. A supplementary food supply (approximately $2100 \mathrm{Kcal}$ per crewmember) is also provided on board for snacking. Before each mission, Shuttle crewmembers select their own menus for the in-flight period; these menus are adjusted as necessary to provide adequate energy and nutrient content. Energy requirements 
are calculated from the Harris-Benedict equation for basal energy expenditure (BEE) (5), which accounts for height, weight, age, and gender. Male crewmembers are judged to require 1.7 times their BEE, and females 1.6 times their BEE. Nutrient content is calculated to meet the National Academy of Science's Recommended Dietary Allowances.

Some indirect assessments of energy utilization from Space Shuttle flights are presented in Table 8.6. Mean dietary intakes during the first 8 Shuttle missions were calculated from disappearance of food from the food lockers (4); these data were compared to mean atmospheric $\mathrm{CO}_{2}$ produced during each flight (unpublished data). Mean energy utilization per person ranged from 1910 to $3576 \mathrm{Kcal} /$ day; leaving out STS-2, during which a large amount of $\mathrm{CO}_{2}$ was produced, reduces the high end of the range to $2760 \mathrm{Kcal} /$ day. Although these methods are less reliable than those used on Skylab, the energy utilization values are nonetheless similar for the Shuttle and Skylab missions.

Energy utilization has also been calculated from metabolic $\mathrm{CO}_{2}$ production during extravehicular activities (EVAs) on the lunar surface. Energy utilization on the moon ranged from about $120 \mathrm{Kcal}$ to $400 \mathrm{Kcal} /$ hour (12-14). By comparison, preflight EVA training sessions in the Weightless Environment Training Facility (WETF) at Johnson Space Center tended to require more energy than that required for similar activities on the moon (Table 8.7). The energy used in working on the moon fell within the range for similar activities on Earth. Walking on the moon collecting geological samples at $250 \mathrm{Kcal} / \mathrm{hr}$, for example, can be compared to a brisk walk while lifting light objects on Earth (5). The energy expended riding in the lunar rover was very similar to that spent driving an automobile on Earth (5). Energy utilization during Skylab EVAs in space, on the other hand, was remarkably consistent, ranging from 200 to $250 \mathrm{Kcal} /$ hour (14). These data suggest that one might be able to predict the energy required for performing planetary activities with knowledge of requirements for performing similar activities on Earth. 
From studies completed thus far, the total energy intake required to function in space appears to be similar to that required for 1-g activities, i.e., approximately 2000 to 3000 $\mathrm{Kcal} /$ day depending on lean body mass and activity level. This conclusion is far from definite, however, because of the sketchy data from Shuttle flights, and because crew activity levels and performance were not assessed in conjunction with these preliminary energy studies. Russian cosmonauts are reported to consume up to $3200 \mathrm{Kca} /$ day; however, they also exercise daily (2). Studies of how exercise affects energy requirements in space are just beginning. Variables such as energy substrate (carbohydrate, protein, fat), level and type of activity (e.g., exercise countermeasures), and fluid shifts may have a profound effect on energy requirements for space flight. Furthermore, data from Skylab suggest that the relationship of resting energy expenditure to total energy expenditure may differ in space, i.e., energy expenditure at rest may be higher, and energy utilization during physical activity lower, in space compared to 1-g. Studies correlating these potentially confounding factors have yet to be performed.

Horizontal or head-down bed rest is used as a model to mimic microgravity-induced changes in the human musculoskeletal system (15), the advantage being the capability of collecting extensive biochemical data under well-controlled conditions. Shangraw et al. (16) found that 7 days of bed rest did not change blood glucose levels in 6 healthy men; however, their basal plasma glucagon and insulin were higher during bed rest than during the ambulatory-control period (Table 8.8). Furthermore, their glucose and insulin response to glucose tolerance tests were higher during the bed-rest period than during the control period. These results are similar to those of Dolkas and Greenleaf $(17,18)$, who found higher plasma insulin levels --but not plasma glucose levels-- during a glucose tolerance test on day 10 of a 14-day bed rest. These results, which are suggestive of increased carbohydrate utilization during bed rest, are intriguing in light of increased RQ during flight (see above). In the Dolkas study, isotonic exercise during bed rest diminished the hyperinsulinemia, suggesting that isotonic exercise during flight may 
ameliorate the effect of microgravity on carbohydrate metabolism. Interestingly, more body weight was lost during bed rest with isotonic exercise than without exercise, demonstrating that significant energy was used during the exercise (18).

Other investigators from both the US and the USSR have reported slight increases in blood glucose early during flight, followed by a decrease $(19,20)$. In the second expedition of the Salyut-4 orbital station (20), the crew's blood glucose and lactic acid levels rose slightly after 2 days and 7 days of flight relative to preflight values. These authors also noted slight increases in blood glucose and insulin during bed rest. In another study, Grigoriev and coworkers (21) compared blood, insulin, and free fatty acid levels before, one day after, and seven days after flights of 4 to 14 days. Fatty acid levels were lower, and serum insulin levels higher, one day after flight compared to preflight levels; insulin levels remained increased to 7 days after landing. In contrast, they found no preflight-to-postflight differences in blood glucose, lactic acid, or pyruvic acid. Although these data are inconclusive, it is possible that they may reflect a shift to carbohydrate and protein as primary energy substrates. Alternatively, one might speculate that the increased insulin levels during flight are associated with increased lipogenesis, perhaps reflecting a decrease in the efficiency of energy utilization in space. More in-flight data are needed to explore these speculations.

Energy can also be derived from the metabolism of tissues. US and USSR scientists have noted decreases in lean body mass during space flight, which implies catabolism of protein. Stool nitrogen levels in Skylab crewmembers were no different in flight than before flight, indicating that consumed protein was digested normally. In contrast, nitrogen was increased in their urine, suggesting that they were in negative nitrogen balance (Table 8.5). This negative nitrogen balance occurred even during Skylab-4, an 84-day flight, despite adequate to high protein intake (Table 8.2) as well as an energy intake sufficient to maintain body weight after taking fluid loss into account (22). The Soviets have found elevated serum levels of amino acids 
at landing (23); however, it is unclear whether this is a result of the cosmonauts' high-protein diet (2) or perhaps mobilization of amino acids from tissues to the liver. Furthermore, protein synthesis may be depressed in microgravity (24). This hypothesis will be studied in U.S. and European Spacelab flights. In any case, it is clear that crewmembers are using tissue protein for energy. Theoretically, therefore, adjustments in diet and exercise protocols may serve to counter the loss of lean body mass and the use of body protein as an energy source. Verification of this supposition remains to be seen.

Some animal data also exist to supplement the minimal human data available from space flight. Unfortunately, access to animals flown in space is frequently delayed for hours to days, and readaptation to $1-\mathrm{g}$ thus confounds interpretation of results. Nevertheless, a few studies of the effects of microgravity on rats have been performed. Two groups of investigators have analyzed body weight, feed intake, and liver enzyme changes in rats that flew on COSMOS 1887 , and compared the results to control animals under similar housing, lighting and feed conditions $(25,26)$. Interestingly, these rats lost weight during flight. This result was explained as an increase in energy utilization to compensate for heat loss, since the rats were unable to curl up and decrease their surface area in microgravity. These results, although intriguing, suggest that rodents may not be a valid model for determining energy requirements in humans. In a related study, the activity of three microsomal hepatic enzymes (hepatic aniline hydroxylase, ethylmorphine $\mathrm{n}$-demethylase, and $\mathrm{P}_{450}$ cytochrome oxidase) from rats exposed to microgravity was decreased relative to the control rats (26). Although these enzymes are not related directly to energy metabolism, the possibility is raised that enzyme regulation is also affected by microgravity. The lower $T_{3}$ and thyroxine levels and higher corticosterone levels in the microgravity-exposed rats compared to the control rats may suggest endocrinologic changes as well. 
Energy metabolism can also be affected by changes in gastrointestinal (GI) function, which influences the absorption and metabolism of nutrients. Although neurovestibular adaptation is believed to be responsible for the unpleasant GI effects of space motion sickness, the GI effects themselves tend to depress appetite, which leads to reduced food and fluid intake. Approximately $50 \%$ of space travellers show some symptoms of space motion sickness during the first few days in flight; some have experienced illness during the entire mission (27). The decreased GI motility associated with motion sickness, coupled with the reduced food and fluid intake, can easily affect nutritional status after a relatively short time. The presence of motion sickness symptoms can therefore be used as an indirect indicator of potential changes in nutritional status as well as gastrointestinal function.

Another rough estimate of GI function can be made by tracking the number of stools produced, and their wet and dry weight, over time. None of these parameters changed during Skylab missions (Table 8.9). It should be noted, however, that stool number or weight provides no information on the availability or absorption of specific nutrients during space flight. A Russian report suggests that the intestinal microflora may be affected by space flight (28); however, far more data are needed before conclusions can be drawn with certainty.

Gastrointestinal function is also influenced by fluid status and the presence -or absence-of gravitational vectors (28-30). The fluid redistribution that occurs during horizontal bed rest has been shown to slow GI transit time (30). Furthermore, depressed appetite occurs during periods of reduced GI motility (31). Thus, although there is no direct evidence of the effect of microgravity on nutrient and micronutrient availability, clearly this area also needs further exploration.

The effect of space flight on physiological water balance is discussed in detail in the third volume of this series. From a nutritional standpoint, water intake in food and fluid and output in 
stools, urine, and sweat can be used to calculate water used in metabolism and lost to evaporation. In the Skylab missions, total body water was determined using the isotope $\left({ }^{3} \mathrm{H}\right)$ dilution method before and immediately after flight (8). The three crewmembers of the 84-day flight showed changes in total body water of $-900,-600$, and $-900 \mathrm{ml}$ after flight, as compared to preflight values of $+100,+200$, and $+700 \mathrm{ml}$, respectively. Mean urinary and stool water losses for two of these crewmembers were similar before and after flight [urine, $1660 \pm 161$ and 1681 \pm 113 ; stool, $77 \pm 26$ and $61 \pm 81 \mathrm{ml}$. However, water ingested from foods and fluids was significantly higher before flight than during flight ( $3293 \pm 225$ vs $2953 \pm 45 \mathrm{ml} /$ day).

Evaporative water losses before and during flight were $1938 \pm 69 \mathrm{~m} /$ day and $1597 \pm 40 \mathrm{ml} /$ day, respectively; the latter calculation takes the decrease in total body water and water balance during flight into account (8). In order to correct for weight loss in 2 of the 3 crewmembers, evaporative water loss was also calculated in terms of body surface area. These calculations also showed decreased evaporative losses during flight $\left[1096 \pm 39 \mathrm{~m} /\right.$ day $/ \mathrm{m}^{2}$ (preflight) and $903 \pm$ $22 \mathrm{~m} / \mathrm{day} / \mathrm{m}^{2}$ (in flight)]. It should be noted that Skylab atmospheric conditions were different than present-day Orbiter conditions. However, the decrease in evaporative water loss may be due in part to weightlessness, since sweat remains on the skin in microgravity rather than dripping off. Skylab-4 included a fan, which provided increased air convection; however, as noted above, evaporative losses were still lower in flight than they had been before flight. Much research is underway in attempts to elucidate the neuroendocrine mechanisms responsible for maintaining water balance in space.

This review has focused on the energy required to live and work in space. Although wellcontrolled nutritional studies have been few, several conclusions can be drawn from existing data. First, the availability of food and the stool weight during Skylab flights were no different than before flight. It appears that the energy required for performing activities in space is at least as high as for ground-based activities; however, the difference may lie in a change in resting energy utilization in space rather than the actual energy required to perform work in space. The 
persistent negative nitrogen balance is puzzling, and requires further study in order to develop and apply appropriate countermeasures. Both American and Soviet data suggest that lean body mass may be replaced during flight with fat; this issue too needs to be addressed. Finally, the results from one Soviet study with rats suggest that rodents may not be the best model for determining energy requirements in humans. Water balance studies also performed during Skylab suggest that space flight does not affect total fluid loss in stool and urine, but may decrease fluid intake and evaporative loss.

For the future, research in energy utilization during space flight must include the development of reliable predictions of energy requirements, particularly for long-duration flights. In light of evidence of elevated blood glucose levels and increased RQ during flight, the best balance of substrate (carbohydrate or fat) for maintaining optimal metabolism should be determined. The role of exercise in negative nitrogen balance, and potentially concurrent reductions in strength, must be investigated. Finally, little information is available concerning the role of micronutrients such as vitamins in energy utilization. Although significant progress has been made, more research is needed to ensure that as flights lengthen, space crews can remain healthy and perform optimally in space. 


\section{REFERENCES}

1. Johnson, P.C., Leach, C.S., Rambaut, P.C. Estimates of fluid and energy balances on Apollo 17. Aerospace Medicine 1973, Vol. 44, No. 11, pp. 1227-1230.

2. Bychko, V.P., Ushakov, A.S., Kalandarov, S., Markaryan, M.V., Sedova, Ye A., Sivuk, A.K., Khokhlova, O.S. Diet of crew in Salyut-6 orbital station. Kosmicheskaya Biologiya I Aviakosmicheskaya Meditsina 1982, Vol. 16, No. 2, pp. 10-13.

3. Rambaut, P.C., Leach, C.S., Leonard, J.I. Observations in energy balance in man during spaceflight. Am. J. Physiol. 1977, Vol. 233, No. 5, pp. R208-212.

4. Stadler, C.R., Rapp, R.M., Bourland, C.T., Fohey, M.F. Space Shuttle Food-System Summary, 1981-1986. NASA Technical Memorandum No. 100 469, Washington DC, NASA, 1988, 335 pp.

5. Bursztein, S., Elwyn, D.H., Askanazi, J., Kinney, J.M. (eds) Energy Metabolism, Indirect Calorimetry and Nutrition. Baltimore, Maryland, Williams and Wilkins, 1989.

6. Thornton, W.E., Ord, J. Physiological mass measurements in Skylab. In: Biomedical Results from Skylab, Johnson, R.S., Dietlein, L.F. (eds). Washington, DC, NASA, 1977, pp. 175-182.

7. Thornton, W.E., Hoffler, G.W., Rummel, J.A. Anthropometric changes and fluid shifts. In: Biomedical Results from Skylab, Johnson, R.S., Dietlein, L.F. (eds). Washington, DC, NASA, 1977, pp. 330-338. 
8. Leach, C.S., Leonard, J.I., Rambaut, P.C., Johnson, P.C. Evaporative water loss in man in a gravity-free environment. J. Appl. Physiol. 1978, Vol. 45, No. 3, pp. 430-436.

9. Leach, C.S. An overview of the endocrine and metabolic changes in manned space flight. Acta Astronautica 1981, Vol. 8, No. 9-10, pp. 977-986.

10. Leonard, J.I., Leach, C.S., Rambaut, P.C. Quantitation of tissue loss during prolonged space flight. Am. J. Clin. Nutr. 1983, Vol. 38, pp. 667-679.

11. Michel, E.L., Rummel, J.A., Sawin, C.F., Buderer, M.C., Lem, J.D. Results of Skylab medical experiment M171-metabolic activity. In: Biomedical Results from Skylab, Johnson, R.S., Dietlein, L.F. (eds). Washington, DC, NASA, 1977, pp. $372-$ 387.

12. Waligora, J.M., Hawkins, W.R., Humbert, G.F., Nelson, L.J., Vogel, S.J., Kuznetz, L.H. Apollo experience report: Assessment on metabolic expenditures. NASA Technical Note No. D-7883, Washington, DC, NASA, 1975.

13. Waligora, J.M., Horrigan, D.J. Metabolism and heat dissipation during Apollo EVA periods. In: Biomedical Results from Apollo, Johnston, R.S., Dietlein, L.F., Berry, C.A. (eds). Washington, DC, NASA, 1975, pp. 115-128.

14. Waligora, J.M., Horrigan, D.J. Metabolic cost of extravehicular activities. In: Biomedical Results from Skylab, Johnson, R.S., Dietlein, L.F. (eds). Washington, DC, NASA, 1977, pp. 395-399. 
15. Dietrick, J.E., Whedon, G.D., Shorr, E. Effects of immobilization upon various metabolic and physiologic functions of normal man. Am. J. Med. 1948, Vol. 4, pp. 336.

16. Shangraw, R.E., Stuart, C.A., Prince, M.J., Peters, E.J., Wolfe, R.R. Insulin responsiveness and protein metabolism in vivo following bedrest in humans. Am. J. Physiol. (Endocrinol. Metab.) 1988, Vol. 225, pp. E548-E558.

17. Dolkas, C.B., Greenleaf, J.E. Insulin and glucose responses during bedrest with isotonic and isometric exercise. J. Appl. Physiol. 1977, Vol. 46, No. 6, pp. 1033-1038.

18. Greenleaf, J.E., Bernauer, E.M., Juhos, L.T., Young, H.L., Morse, J.T., Staley, R.W. Effects of exercise on fluid exchange and body composition in man during 14-day bedrest. J. Appl. Physiol. 1977, Vol. 43, No. 1, pp. 126-132.

19. Leach, C.S., Alexander, W.C., Johnson, P.C. Endocrine, electrolyte, and fluid volume changes associated with Apollo missions. In: Biomedical Results of Apollo, Johnston, R.S., Dietlein, L.F., Berry, C.A. (eds). Washington, DC, NASA, 1975, pp. 163-184.

20. Tigranyan, R.A., Popova, I.A., Belyakova, M.I., Kalita, N.F., Tuzova, Ye G., Sochilina, L.B., Davydova, N.A. Results of metabolic studies on the crew of the second expedition of the Salyut-4 orbital station. Kosmicheskaya Biologiya I Aviakosmicheskaya Meditsina 1977, Vol xx, No. 2, pp. 48-53.

21. Grigoriev, A.I., Popova, I.A., Ushakov, A.S. Metabolic and hormonal status of crewmembers in short-term space flights. Aviation, Space, and Environmental Medicine 1987, Vol. 58, No. 9, pp. A121-125. 
22. Rambaut, P.C., Johnson, P.C. Nutrition. In: Space Physiology and Medicine, Nicogossian, A.E., Huntoon, C. L., Pool, S. L. (eds). Philadelphia, Lea and Febiger, 1989, pp. 202-213.

23. Popov, I.G., Latskevich, A.A. Effect of 140-day flight on blood amino acid levels in cosmonauts. Kosmicheskaya Biologiya I Aviakosmicheskaya Meditsina 1983, Vol. 17, No. 2, pp. 23-30.

24. Schonheyer, F., Heilskov, N.S.C., Olesen, K. Isotopic studies of the mechanism of negative nitrogen balance produced by immobilization. Scan. J. Clin. Invest. 1954, Vol. 6, pp. 178-188.

25. Grindeland, R.E., Popova, I.A., Vasques, M., Arnaud, S.B. Cosmos 1887 mission overview: effects of microgravity on rat body and adrenal weights and plasma constituents. FASEB J 1990, Vol. 4, pp. 105-109.

26. Merrill, A.H., Hoel, M., Wang, E., Mullins, R.E., Hargrove, J.L., Jones, D.P., Popova, I.A. Altered carbohydrate, lipid, and xenobiotic metabolism by liver from rats flown on Cosmos 1887. Fed. Proc. 1990, Vol. 4, pp. 95-100.

27. Homick, J. L. and Vanderploeg, J. M. The neurovestibular system. In: Space Physiology and Medicine. Nicogossian, A.E., Huntoon, C.L., Pool, S.L. (eds). Philadelphia, Lea and Febiger, 1989, pp. 154-166.

28. Smirnov, K.V., Lizko, N.N. Problems of space gastroenterology and microenvironment. Die Nahrung 1987, Vol. 31, pp. 563-566. 
29. Nimmo, W.S., Prescott, L.F. The influence of posture on paracetamol absorption. Br. J. Clin. Pharmac.1978, Vol. 5, pp. 348-349.

30. Groza, P. Digestive reactions to simulated and real space flight. Physiologie 1988, Vol. 25, pp. 207-231.

31. Meyer, J.H. Motility of the stomach and gastroduodenal junction. In: Physiology of the Gastrointestinal Tract, 2nd ed. Johnson, L.R. (ed). New York, Raven Press, 1987, pp. 613-629. 
Table 8.1. Energy Expenditure in Selected Household, Recreational, and Sports Activities

\begin{tabular}{|c|c|c|}
\hline Activity & $\begin{array}{l}\text { Energy Expended } \\
\left(\mathrm{kcal} \mathrm{min}^{-1} \mathrm{~kg}^{-1}\right)\end{array}$ & $\begin{array}{l}\text { Energy expended }(\mathrm{kcal} / \mathrm{min}) \\
\text { for a } 80-\mathrm{kg}(176-\mathrm{lb}) \text { person }\end{array}$ \\
\hline Archery & 0.065 & 5.2 \\
\hline Badminton & 0.097 & 7.8 \\
\hline Basketball & 0.138 & 11.0 \\
\hline Bookbinding & 0.038 & 3.0 \\
\hline Card playing & 0.025 & 2.0 \\
\hline General carpentry & 0.052 & 4.2 \\
\hline \multicolumn{3}{|l|}{ Circuit training: } \\
\hline Hydra-fitness & 0.132 & 10.56 \\
\hline Universal & 0.116 & 9.28 \\
\hline Nautilus & 0.092 & 7.36 \\
\hline Free weights & 0.086 & 6.88 \\
\hline Cleaning $(F)$ & 0.062 & 4.96 \\
\hline Cleaning (M) & 0.058 & 4.64 \\
\hline Cooking (F) & 0.045 & 3.60 \\
\hline Cooking (M) & 0.048 & 3.84 \\
\hline \multicolumn{3}{|l|}{ Cycling: } \\
\hline at $5.5 \mathrm{mph}$ & 0.064 & 5.12 \\
\hline at $9.4 \mathrm{mph}$ & 0.090 & 7.20 \\
\hline racing & 0.169 & 13.52 \\
\hline Drawing (standing) & 0.036 & 2.88 \\
\hline Eating (sitting) & 0.023 & 1.84 \\
\hline Electrical work & 0.058 & 4.64 \\
\hline Fishing & 0.062 & 4.96 \\
\hline Golfing & 0.085 & 6.80 \\
\hline Gymnastics & 0.066 & 5.28 \\
\hline Lying at ease & 0.022 & 1.76 \\
\hline Painting, inside & 0.034 & 2.72 \\
\hline Painting, outside & 0.077 & 6.16 \\
\hline
\end{tabular}


Table 8.1, continued

\begin{tabular}{lcc}
\hline & $\begin{array}{c}\text { Energy Expended } \\
\left(\mathrm{kcal} \mathrm{min}^{-1} \mathrm{~kg}^{-1}\right)\end{array}$ & $\begin{array}{c}\text { Energy expended (kcal/min) } \\
\text { for a 80-kg (176-lb) person }\end{array}$ \\
Activity & & \\
\hline Running, cross-country & 0.163 & 13.04 \\
Running, 11.5 min/mile & 0.135 & 10.80 \\
Running, 7 min/mile & 0.228 & 18.24 \\
Scrubbing floors (F) & 0.109 & 8.72 \\
Scrubbing floors (M) & 0.108 & 8.64 \\
Sitting quietly & 0.021 & 1.68 \\
Snowshoeing, soft snow & 0.166 & 13.28 \\
Standing quietly (F) & 0.025 & 2.00 \\
Standing quietly (M) & 0.027 & 2.16 \\
Table tennis & 0.068 & 5.44 \\
Tennis & 0.109 & 8.72 \\
Typing (electric) & 0.027 & 2.16 \\
Typing (manual) & 0.031 & 2.48 \\
Walking, normal pace & & 6.40 \\
asphalt road & 0.080 & 2.32 \\
fields and hillsides & 0.082 & \\
Writing (sitting) & 0.029 & \\
\hline & & \\
\hline & & \\
\hline
\end{tabular}

Adapted from McArdle, W.D., Katch, F. I., \& Katch, V. L., Exercise Physiology: Energy, Nutrition, and Human Performance, 2nd Edition. Philadelphia: Lea and Febiger, Appendix D, pp. 642-649, 1986. 


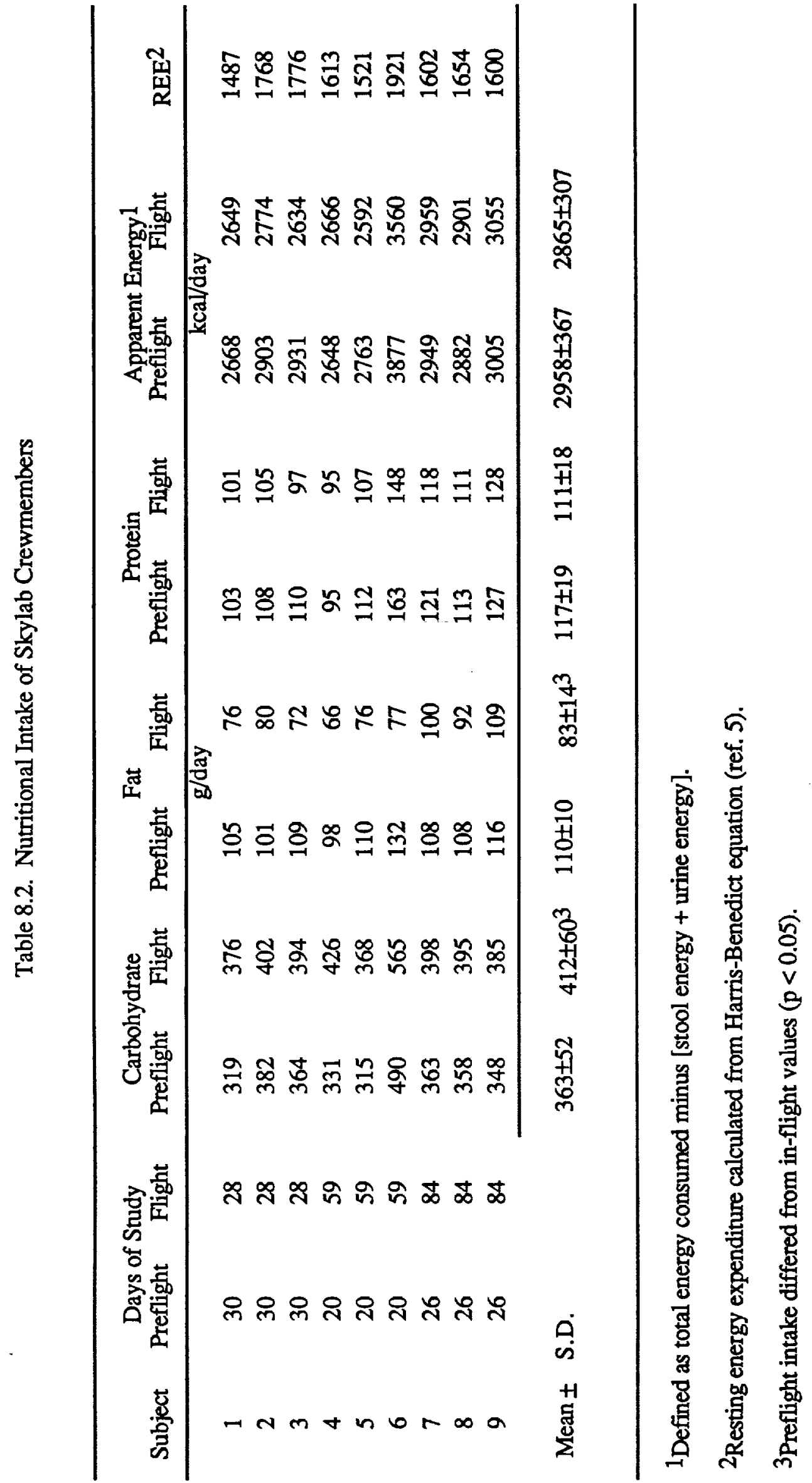




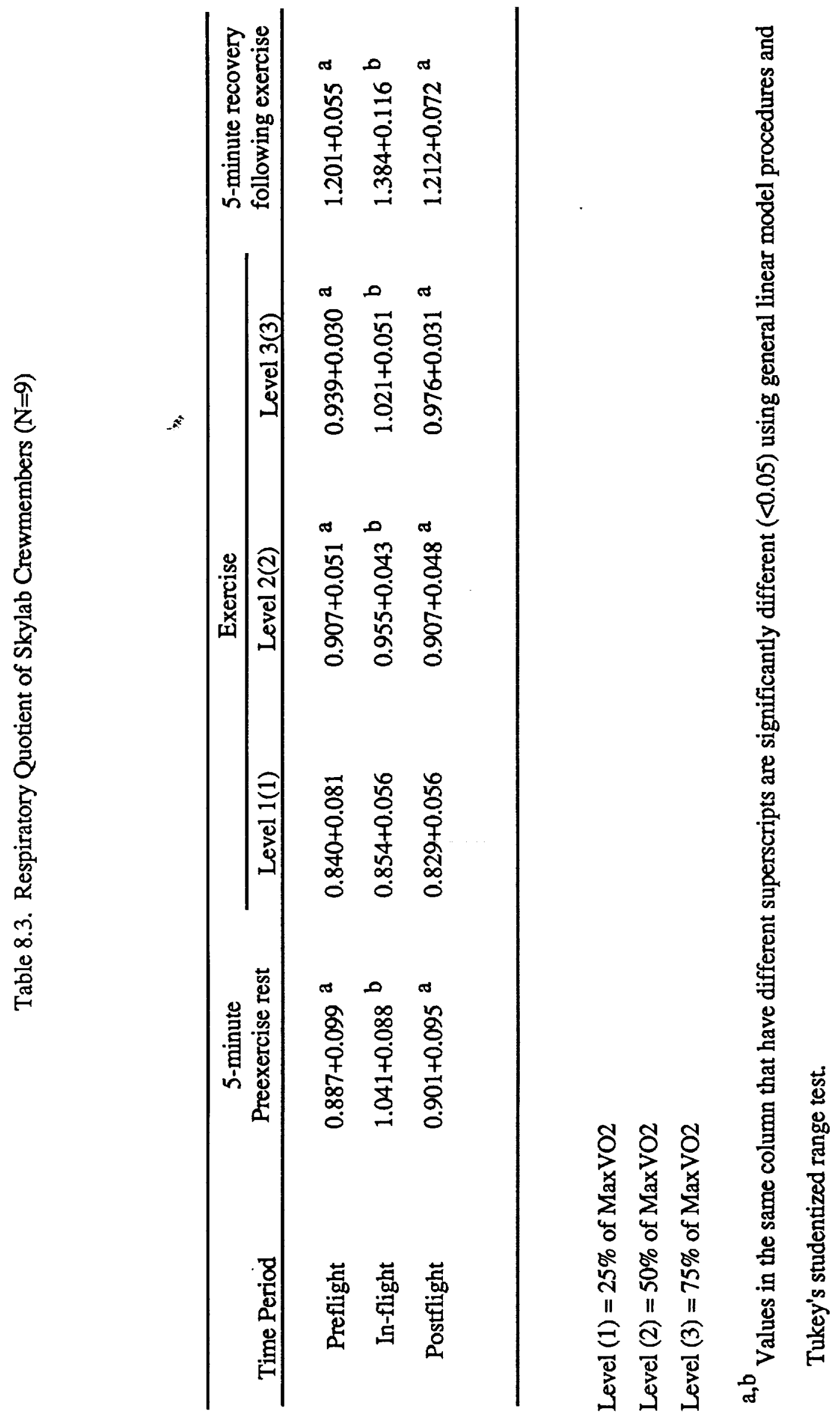


Table 8.4. Thermal Equivalent of Oxygen for Nonprotein Respiratory Quotient

\begin{tabular}{|c|c|c|c|c|c|c|}
\hline \multirow[t]{2}{*}{ Nonprotein RQ } & \multirow{2}{*}{\multicolumn{2}{|c|}{$\begin{array}{l}\mathrm{Kcal} / \mathrm{LO}_{2} \\
\text { Consumed }\end{array}$}} & \multicolumn{2}{|c|}{$\%$ Derived from } & \multicolumn{2}{|c|}{$\mathrm{g} / \mathrm{L} \mathrm{O} 2$ Consumed } \\
\hline & & & Carbohydrate & Fat & Carbohydrate & Fat \\
\hline 0.707 & & 4.686 & 0 & 100 & 0.000 & .496 \\
\hline .71 & & 4.690 & 1.10 & 98.9 & .012 & .491 \\
\hline .72 & & 4.702 & 4.76 & 95.2 & .051 & .476 \\
\hline .73 & & 4.714 & 8.40 & 91.6 & .090 & .460 \\
\hline .74 & & 4.727 & 12.0 & 88.0 & .130 & .444 \\
\hline .75 & & 4.739 & 15.6 & 84.4 & .170 & .428 \\
\hline .76 & $y$ & 4.751 & 19.2 & 80.8 & .211 & .412 \\
\hline .77 & & 4.764 & 22.8 & 77.2 & .250 & .396 \\
\hline .78 & & 4.778 & 26.3 & 73.7 & .290 & .380 \\
\hline .79 & & 4.788 & 29.9 & 70.1 & .330 & .363 \\
\hline .80 & & 4.801 & 33.4 & 66.6 & .371 & .347 \\
\hline .81 & & 4.813 & 36.9 & 63.1 & .413 & .330 \\
\hline .82 & & 4.825 & 40.3 & 59.7 & .454 & .313 \\
\hline .83 & & 4.838 & 43.8 & 56.2 & .496 & .297 \\
\hline .84 & & 4.850 & 47.2 & 52.8 & .537 & .280 \\
\hline .85 & & 4.862 & 50.7 & 49.3 & .579 & .263 \\
\hline .86 & & 4.875 & 54.1 & 45.9 & .621 & .247 \\
\hline .87 & & 4.887 & 57.5 & 42.5 & .663 & .230 \\
\hline .88 & & 4.899 & 60.8 & 39.2 & .705 & .213 \\
\hline .89 & & 4.911 & 64.2 & 35.8 & .749 & .195 \\
\hline .90 & & 4.924 & 67.5 & 32.5 & .791 & .178 \\
\hline .91 & & 4.936 & 70.8 & 29.2 & .834 & .160 \\
\hline .92 & & 4.948 & 74.1 & 25.9 & .877 & .143 \\
\hline .93 & & 4.961 & 77.4 & 22.6 & .921 & .125 \\
\hline .94 & & 4.973 & 80.7 & 19.3 & .964 & .108 \\
\hline .95 & & 4.985 & 84.0 & 16.0 & 1.008 & .090 \\
\hline .96 & & 4.998 & 87.2 & 12.8 & 1.052 & .072 \\
\hline .97 & & 5.010 & 90.4 & 9.58 & 1.097 & .054 \\
\hline .98 & & 5.022 & 93.6 & 6.37 & 1.142 & .036 \\
\hline .99 & & 5.035 & 96.8 & 3.18 & 1.186 & .018 \\
\hline 1.00 & & 5.047 & 100.0 & 0 & 1.231 & .000 \\
\hline
\end{tabular}

Reproduced from McArdle, W.D., Katch, F. I., \& Katch, V. L., Exercise Physiology: Energy, Nutrition, and Human Performance, 2nd Edition. Philadelphia: Lea and Febiger, p. 127, 1986. 
Table 8.5. Body Weight Changes and Nitrogen Balancein Skylab Crewmembers

\begin{tabular}{|c|c|c|c|c|c|}
\hline Crewmember & & $\begin{array}{l}\text { Length of } \\
\text { Flight }\end{array}$ & $\begin{array}{l}\text { Change in } \\
\text { Body Weight } \\
\text { Preflight-to-In-flight }\end{array}$ & $\begin{array}{r}\begin{array}{l}\text { Nitrogen } \\
\text { Balance } \\
\text { Preflight }\end{array} \\
\text { P }\end{array}$ & In-Flight \\
\hline & 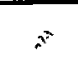 & (days) & (lbs) & g/day & \\
\hline 1 & & 28 & -5 & 2.95 & -0.96 \\
\hline 2 & & 28 & -5 & 3.12 & -2.22 \\
\hline 3 & & 28 & -5 & 3.00 & -1.71 \\
\hline 4 & & 52 & -8 & 3.07 & -0.99 \\
\hline 5 & & 52 & -6 & 3.42 & -0.78 \\
\hline 6 & & 52 & -6 & 4.05 & -0.81 \\
\hline 7 & & 84 & -2 & 3.31 & -1.24 \\
\hline 8 & & 84 & -4 & 2.20 & -0.68 \\
\hline 9 & & 84 & -3 & 2.78 & -0.06 \\
\hline
\end{tabular}

${ }^{1}$ Adapted from ref. 10. Used with permission. 
Table 8.6. Estimates of Energy Utilization during 8 U.S. Space Shuttle Flights

\begin{tabular}{lllll}
\hline $\begin{array}{l}\text { Shuttle } \\
\text { Mission } \\
\text { Number }\end{array}$ & \# Crewmembers & $\begin{array}{l}\text { Mean Energy } \\
\text { Calculated from } \\
\text { Food Disappearance }\end{array}$ & $\begin{array}{l}\text { Mean Energy } \\
\text { Calculated from } \\
\text { CO2 Production }\end{array}$ & Difference \\
\hline & 2 & Kcal/day/person & & \\
1 & 2 & 2565 & 2568 & $0 \%$ \\
2 & 2 & 2200 & 3576 & $62 \%$ \\
3 & 2 & 1910 & 2688 & $41 \%$ \\
4 & 2 & 2446 & 2616 & $7 \%$ \\
5 & 4 & 2322 & 2712 & $17 \%$ \\
6 & 5 & 1957 & 2664 & $36 \%$ \\
7 & 5 & 2535 & 2424 & $-4 \%$ \\
8 & 5 & 2517 & 2760 & $10 \%$ \\
\hline
\end{tabular}

Adapted with permission from Lane, H.W. Energy requirements for space flight. J. Nutr. 1992, Vol. 122, pp. 13-18. 
Table 8.7. Metabolic Rates During Extravehicular Activities: 1-g Training and During Flight (Apollo 15) 1

\begin{tabular}{lll}
\hline & $\begin{array}{l}\text { Energy Expended } \\
\text { During Training in } \\
\text { Neutral Buoyancy } \\
(1-\mathrm{g})\end{array}$ & $\begin{array}{l}\text { Energy Expended } \\
\text { During Actual EVA } \\
\text { on the Lunar Surface }\end{array}$ \\
\hline Type of Activity & 445 & $\mathrm{kcal} / \mathrm{hr}$ \\
Station & 203 & 228 \\
Lunar rover & 393 & 123 \\
Average of activities & & 230 \\
\hline
\end{tabular}

1

Ref. 13 


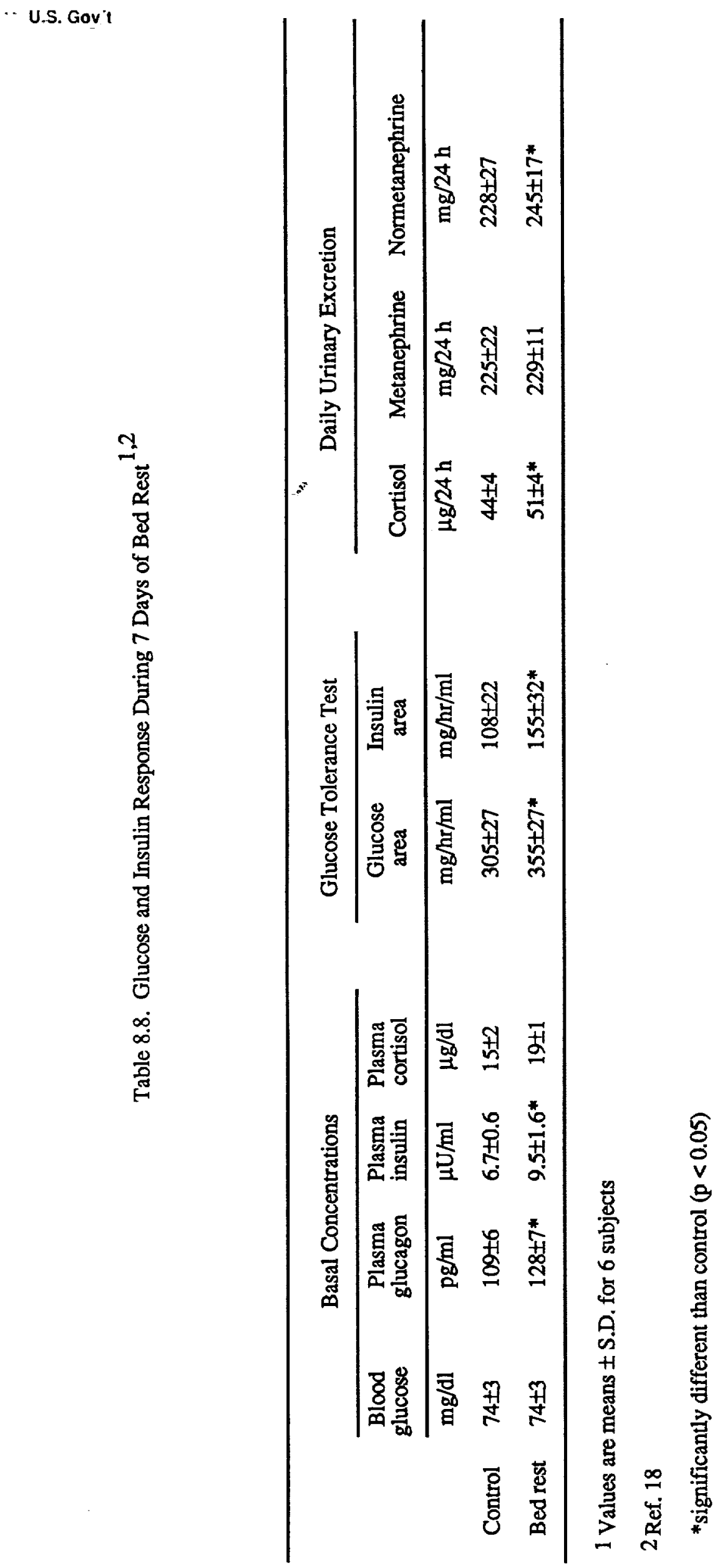


U.S. Gov't

Table 8.9. The Effect of Space Flight on Stool Production in 9 Skylab Crewmembers

\begin{tabular}{llll}
\hline & \# Stools/Day & Wet Weight & Dry Weight \\
\hline Preflight & $0.72+0.19$ & \multicolumn{2}{c}{$(\mathrm{g})$} \\
In-Flight & $0.54+0.26$ & $81.5+33.6$ & $25.4+4.7$ \\
Postflight & $0.55+0.2$ & $69.9+19.0$ & $23.9+4.8$ \\
& & $51.4+35.4$ & $23.6+6.1$ \\
\hline
\end{tabular}


U.S.Govt REPOPT DOCUNERTATION PAGE

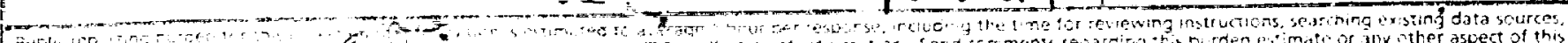

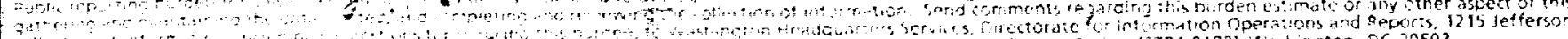

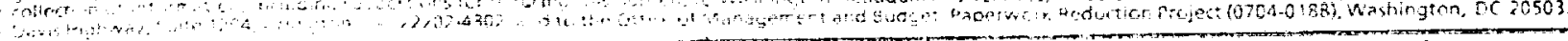

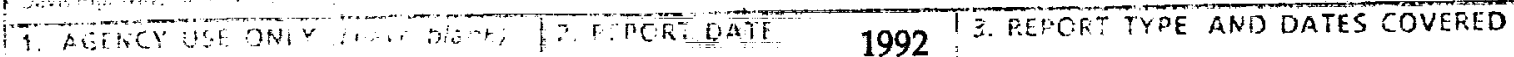

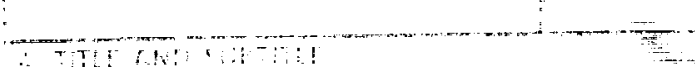
(1)

o : Metabolic Energy Requirements for Space Flight

(1). A. 015

Helen W. Lane, Ph.D.

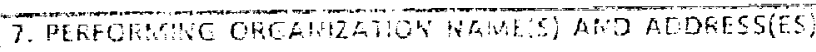

Lyndon B. Johnson Space Center

Houston, TX 77058

9. SPONSORING /MONITORIIU AGERCY NAME(S) ANO ADDRESS(ES)

10. SPONSORING IMONITORING AGENCY REPORT NUMBER

National Aeronautics and Space Administration

Washington, DC

11. SUPPLEMENTARY NOTES

To appear in Foundations in Space Biology and Medicine, Vol. II, Chapter 8

Published by the American Institute of Aeronautics and Astronautics, 1992

\begin{tabular}{|l|l|l|l|l|}
\hline 12a. DISTRIBUTION/AVALIAEHEITY STATFMENT & DISTRIBUTION CODE \\
Unclassified/Unlimited &
\end{tabular}

13. AESTFACT MPXITUM

The international space community, including the USSR, Japan, Germany, the European Space Agency, and the United States, is preparing for extended stays in space. Much of the research planned for space will be tended by humans; thus maintaining adequate nutritional status during long stays in space has lately become an issue of much interest. Historically, it appears that minimum nutritional requirements are being met during stays in space: Thus far, crewmembers have been able to consume food adequate for maintaining nominal performance in microgravity. The purpose of this review is to explore the physiological data obtained from ground-based and flight research that may enable us to understand the biochemical alteration! that affect energy utilization and performance. This review will focus on energy utilization during the Apollo lunar missions, Skylab's extended space lab missions, and Space Shuttle flights. Available data includes those recorded during intra- and extravehicular activities as well as during microgravity simulation (bed rest). Data on metabolism during flight and during bed rest will be discussed, with a follow-up on humar gastrointestinal function.

14. SUBJECT TERMS

space, humans, energy utilization, metabolism, nutritional status

17. SECURITY CIASSIFICATION
$\begin{aligned} & \text { OF REPCRT } \\ & \text { unclassified }\end{aligned}$

19. SECURITY CLASSIFIGATION OF A.ESTRACT

NSN 7540-01-280-5500 